\title{
Dark Tourism: Understanding the Concept and Recognizing the Values
}

\author{
Ramesh Raj Kunwar, PhD \\ APF Command and Staff College, Nepal \\ Email: kunwar.dr@gmail.com \\ Neeru Karki \\ Department of Conflict, Peace and Development Studies, TU \\ Email: neeru.karki@gmail.com
}

'Man stands in his own shadow and wonders why it's dark' (Zen Proverb; in Stone, Hartmann, Seaton, Sharpley \& White, 2018, preface).

\begin{abstract}
Dark tourism is a youngest subset of tourism, introduced only in 1990s. It is a multifaceted and diverse phenomenon. Dark tourism studies carried out in the Western countries succinctly portrays dark tourism as a study of history and heritage, tourism and tragedies. Dark tourism has been identified as niche or special interest tourism. This paper highlights how dark tourism has been theoretically conceptualized in previous studies. As an umbrella concept dark tourism includes than tourism, blackspot tourism, morbid tourism, disaster tourism, conflict tourism, dissonant heritage tourism and others. This paper examines how dark tourism as a distinct form of tourism came into existence in the tourism academia and how it could be understood as a separate subset of tourism in better way. Basically, this study focuses on deathscapes, repressed sadism, commercialization of grief, commoditization of death, dartainment, blackpackers, darsumers and deathseekers capitalism. This study generates curiosity among the readers and researchers to understand and explore the concepts and values of dark tourism in a better way.
\end{abstract}

Keywords: Dark tourism, authenticity, supply and demand, emotion and experience

\section{Introduction}

Tourism is a complex phenomenon involving a wide range of people, increasingly seeking for new and unique experiences in order to satisfy the most diverse motives, reason why the world tourism landscape has been changing in the last decades (Seabra, Abrantes, \& Karstenholz, 2014; in Fonseca, Seabra, \& Silva, 2016, p. 1). The concept of pleasant diversion in pleasant places' is changing and broadening into new market demanding, more complex and even unusual (Wight, 2006; in Fonseca et al., 2006). The questions are how dark tourism studies got introduced in the academia? What is the significance of dark tourism and how does it defer from other types of tourism? How could it be promoted in the new places where dark tourism is viable? The purpose of this study is to advance knowledge and understand the phenomenon of dark tourism.

The concept of dark tourism and thantourism has created an opportunity for tourism researchers to explore new issues and push the boundaries of tourism research in new directions (Ashworth \& Issac, 2015; Johnstone, 2011; in Light, 2017, p. 93). Over the past decade dark tourism (and, to a lesser extent, thanatourism) have become established as mainstream research topics within tourism studies/tourism management, and are the focus of vigorous debate and critique.

The term 'dark' describes alludes to a sense of apparent disturbing practices and morbid products and experience, within the tourism domain (Stone, 2006, p. 146). The attention given to events of death, suffering, and atrocity and the subsequent development of dark tourism sites is attributed to an inherent curiosity towards mortality and the darker aspects of humanity (Foley, 2009; in Fonseca et al., 2016, p. 1). Humanity has been interested in the end of life since the time of pilgrimages (Titta, 2010). Death is clearly one such issue that raises uncertainties and anxieties and hence becomes a major issue to bracket out of everyday consciousness, contemplating death as taboo. Berger's (1967) seminal text suggested death was essential feature of human condition, requiring individual to develop mechanisms to cope with their ultimate demise. Commentators are now challenging death taboos by exploring contexts where the dead share world with living justified by Harrrison's $(2003,2004)$ logic of absorption done through graves, images, literature, architecture and monuments, Lee's (2002) concept of disenchantment of death that advocates death as 'coming out of the closet to redefine our assumptions of life'. As Bauman (1992, p. 10; in Davidson, 2008, p. 15) observes of survival, it can be more about outliving others than about our own longevity: 'we never live through our death, but we do live through the deaths of others, and their death gives meaning to our success: we are still alive'. 
According to Seaton (1996), the relationship between death and tourism, or 'thanatourism', intensified from the nineteenth century onwards, but it is only more recently that 'dark tourism' has become the focus of increasing academic attention (Biran \& Hyde, 2013; Sharpley \& Stone, 2009; Stone, 2013). There is broader growth of interest in issues of death and dying within the social sciences as the growing profile of 'death studies' as a multidisciplinary research focus testifies (Light, 2017,p.293). An Institute of Dark Tourism Research (IDTR) has been established at the University of Central Lancashire (UK) (Light, 2017, p. 276). Once recognized as a phenomenon several countries have tried to integrate dark tourism as a product into their tourism industry (Blom, 2000). Many destinations around the world implemented structures to support this new offer, playing dark tourism an important role in both a country's economy and its image. Thereby, for the individual who wishes to journey and gaze upon real or recreated death, plethora of sites, attractions and exhibitions are, new emerging across the world to cater to the 'dark side of travel' (Sharpley \& Stone, 2009).

'Dark Tourism' was first coined by Foley and Lennon (1996a, 1996b) in a special issue of the International Journal of Heritage Studies, their analysis relates primarily to 'the presentation and consumption of real and commodified death and disaster sites. However, the work was not the first to draw attention to the phenomenon of 'darkness' in tourism. In 1989, Uzzell (1989) discussed hot interpretation of war and conflict sites (see Sharpley, 2009). In addition, Rojek (1993) discussed the emergence of 'black spots' which "refer to the commercial developments of grave sites and sites in which celebrities or large number of people have met with sudden and violent death" (p. 136; in Raine, 2013, p. 249). Another early reflection on dark tourism includes Seaton's reference to 'thantourism' (p. 15) and Tunbridge and Asworth (1996, p. 114; in Raine, 2013, p. 243) and introducing the term ' horror tourism' (p. 129; in Raine, 2013) which they explored in terms of heritage management. However, the focus on the relationship between sites associated with war, death and atrocity was included in heritage tourism context which explains 'dissonant heritage' (Tunbridge \& Asworth, 1996) 'sensitive heritage' (Frew, 2012), 'contested heritage' (Naef \& Ploner, 2016) and 'industrial heritage' and ghost town (Delyser, 1999; Meheman, 2011; Stone, 2016; Tang, 2018).

Although the term "dark tourism" is used by the authors of this study various synonymous terms are used in literatures, for example dark tourism has been referred to the "thanatourism" (Seaton, 2001), " milking the macabre", " the dark side of tourism" (Dann,1998; in Dann \& Seaton,2001), "tragedy tourism", and "mea culpa tourism" (Richter, 1999 ; in Dann \& Seaton, 2001). In order to understand dark tourism in better way, first and foremost it is noteworthy to mention how dark tourism as an important product came into existence. Later refined by their assertion that dark tourism is 'an intimation of postmodernity' (Lennon \& Foley, 2000:11). That is, firstly, interest in and the interpretation of events associated with death is to a great extent dependent on the ability of global communication technology to instantly report them and subsequently repeat ad infinitum (hence time-space compression). Secondly, it is claimed that most dark tourism sites challenge the inherent order, rationality and progress of modernity. Thirdly, at most sites the boundaries between the message and their commercialization as tourist products have become increasingly blurred. Lennon and Foley's aforementioned temporal positioning of dark tourism as a modern or 'within living memory' phenomenon remains an issue of contention with other literatures i.e. Ryan and Kohli's (2006) study of 'buried village' in New Zealand in 1886- concurs with Lennon and Foley's idea. That is, the experiences of contemporary tourists at the site are multifaceted and not predominantly related to disaster in 1886.

Generally, there are two distinct bases for analysis is evident in the emergent work of dark tourism. On one hand, Seaton explores dark tourism or thanatourism as a behavioral phenomenon, pointing to the existence of 'dark tourist' or 'thanatourist'. Thus, for Seaton, thanatourism is a form of tourism consumption. On the other hand, significant attention is paid to dark sites or attractions- the objects of dark tourism consumption- in general, and their definition, interpretation and management in particular. In either case, however, little attempt is made to delve beneath the surface of these issues, to explore differing approaches to and meanings of dark tourism's demand and supply. Seaton and Lennon (2004; in Farmaki; 2013, p. 282) identified two main motives related to dark tourism:

- Schadenfreude (i.e. the pleasure of seeing others' misfortune and ;

- Thanatopsis (i.e. the contemplation of death). 


\section{4 | Journal of APF Command and Staff College}

According to Seaton (1996), there are just five possible categories of dark travel activity: 1. to witness public enactments of death; 2 . to sites of individual or mass deaths; 3 . to memorials or internment sites; 4 . to see symbolic representations of death; 5 . to witness re-enactments of death.

Accordingly, whoever studied on different aspects of dark tourism they have defined their own perceptions, although the crux of study is multi-layered mixture of history and heritage, tourism and tragedies. In this way scholars defined dark tourism on their own way which has been cited by Light (2017). Since, 1996 to 2017, Light has listed more than 171 scholars who have conducted research on various aspects of dark tourism and defined it on the basis of practices, types of places, motivations, form of experiences and heritage. Overall, Light (2017) has compiled few important definitions of dark tourism through the tabular representation.

There is a growth in number of visitors to dark tourism sites in recent years. For example, in 2010, nearly 8,00,000 tourists visited the Jewish Museum Berlin, a record since its opening in 2001 (Plocki \& Plagemann, 2011; in Isaac \& Çakmak, 2014, p. 164), while the Anne Frank House and Alcatraz Prison ( Rheenen, 2011; in Isaac \& Çakmak, 2014) have received more than one million visitors annually. Arlington National Cemetery in Virginia has more than four million visitors, and perhaps the most iconic dark tourism site, the Auschwitz Concentration Camp reached another record number of visitors in 2011, with almost 1, 400,000 ( Auschwitz- Birkenau Memorial and Museum, 2011; in Isaac \& Çakmak, 2014, pp.164-165).

Dark Tourism scholars have diversified the notion of death-related tourist activity as 'thanatourism' (Dann, 1994 ; Seaton 1996), ' black-spot tourism' (Rojek 1993), 'morbid tourism’ (Blom, 2000), ' grief tourism' (O' Neill,2002 ; Trotta, 2006) and 'atrocity tourism' (Ashworth,2002), phoenix tourism (Causevic \& Lynch,2011), natural disaster tourism (Miller,2008; in Ashworth \& Isaac, 2015, p. 3), disaster tourism (Antick, 2013), hot-spot tourism (Pelton, 2003;in Ashworth and Isaac, 2015, p. 3), holocaust tourism (Buntman,2008), prison tourism (Strange \& Kempa, 2003; in Fonseca, Seabra \& Silva, 2016), cemetery tourism( Abranja,2012; in Fonseca, Seabra \& Silva, 2016), ghost tourism (Davies, 2007; in Fonseca, Seabra \& Silva, 2016), battlefield tourism ( Henderson, 1997; in Seaton, 2012, p. 522), conflict tourism (Ryan \& Kohli , 2006) (involving visits to places which are under threat) and produce a typology comprising plantation tourism, suicide tourism and doomsday tourism (Trotta, 2006; in Simone-Charteris, Boyd, \& Burns, 2013, p. 63), negative sightseeing (MacCannell, 1976), tragic tourism (Lippard, 1999), slumming (Kirshenblatt-Gimblett, 1998), strange tours (Weiner, 2008), poorism (Popescu, 2007).

In course of doing research, scholars have developed various types of dark tourism which are cited by Kuznik (2015, pp. 331-332; Fonseca, Seabra, \& Silva, 2016, p. 3; Titta, 2010, pp. 13-14). Kuznik (2015) highlights following types of dark tourism: grave tourism-visiting famous cemeteries; war or battlefield tourism-visiting former war places; holocaust tourism-visiting concentration camp and memorial sites with cruel history; genocide tourism-visiting places of genocide; prison tourism-visiting former sites of punishment that have dark history attached and that combines education and entertainment; communism tourism-visiting places where communism was originated and existed; cold war and iron curtain tourismseeking out traces and remains of Berlin wall; disaster area tourism- visiting places of natural disasters; nuclear tourism-visiting sites of civil nuclear disaster; murderers and murderous places tourism- visiting spots where murderous act occurred; slum tourism/favela tourism -visiting impoverished areas; terrorist tourism- visiting areas where terrorist acts occurred; paranormal tourism-visiting places where paranormal activities are traced; witched tourism/ghost tourism- visiting places, allegedly proceeding ghost haunting; accident tourism-visiting vehicle accident sites; icky medical tourism-visiting body world museum and sites; dark amusement tourism- visiting dark experiences themed amusement parks.

In developing a typology of dark tourism consumption, Sharpley (2005) draws upon Holt's (1995) earlier typology of consumption practice in which four 'metaphors' of consumption are proposed:

- Dark tourism as experience: may be consumed in order to give phenomenological meaning to tourist's own social existence by visiting war cemeteries/memorials; paler fantasy; battlefields and other war related museums or attractions.

- Dark tourism as play: Representing 'paler' experiences, consumption as play focuses upon the shared, communal consumption of dark tourism sites or experiences. Death of an individual or group of people is initial driver for collective celebration, remembrance or mourning. Thus, dark 
tourism becomes pilgrimage, or journey followed by the experience of 'communitas'.

- Dark tourism as integration: Two shades of dark tourism as integration. On the one hand with evident links to the notion of consumption as fantasy, tourists may integrate themselves into the object of consumption, the fascination not being in death itself but in broader context within which death occurs. On the other hand, the darkest form is where tourists seek to integrate themselves with death, either through witnessing violent or untimely deaths ( travelling, for example to the scene of disasters or murders) or, in the extreme perhaps, travelling in the knowledge or expectation of death.

- Dark tourism as classification: In the context of dark tourism, status may be sought through undertaking forms of travel that are dangerous for the tourist. This form of consumption falls towards the paler end of dark tourism continuum and demonstrates that fascination with death may often not be the principal factor driving such experiences. If, as Sharpley (2005) proposes, there exists a 'continuum of purpose' of supply of dark tourism attractions, varying from ' accidental' supply to supply that is directly intended to exploit, for profit or otherwise, people's ' thanatopsis'.

More recently, dark tourism has embraced a more materialist, post-human stance, putting relations and affective relationality between a 'now' and a 'them' on the agenda, as a replacement of purely constructivist paradigms (Sather-Wagsatff, 2011; in Knudsen, 2017, p. 174). Stone's (2006) ideas of complexities of defining dark tourism include two propositions that are relevant to this chapter: a) the distinction between purposefully constructed sites attractions or exhibitions that interpret or recreate events or acts associated with death, and the macabre and so called 'accidental' or non-purposeful sites. That is, those sites, such as cemeteries, memorials or disaster sites that have become tourist attractions by 'accident' because of their relationship with turbulent and tragic events; and b) the fundamental reasons why and how dark sites/ experiences are produced or supplied - for example, political reasons, for remembrance purposes, for education, for entertainment or for economic gain.

For a newbie in dark tourism academia having questions on where are dark sites? There are several sites at present which brings past events, sharing information, and causing emotions. Fonseca et al. (2016, pp. 4-5) have collected approximately thirty dark tourist sites worldwide. They are :Concentration and Extermination Camp in Auschwitz, Poland; Ground Zero - The National September 11 Memorial in New York USA; Hiroshima Peace Memorial Park Hiroshima, Japan; The Dracula's Castle - Bran Castle Wallachia (Transylvania);Alcatraz Federal Penitentiary San Francisco Bay (USA); Pompeii Naples, Italy; Leap Castle Coolderry County Offaly, Ireland; Père - Lachaise Paris, France; Squatter Camp Soweto Soweto South Africa; TuolSleng Museum Phnom Penh (Cambodia); Dharavi Slum Mumbai India; Latvian Prison Hotel and Museum Liepāja Latvia ;Alma Bridge Paris France; Arlington National Cemetery Virginia, USA; Paris Catacombs Paris, France ;Titanic Belfast Belfast (Northern Ireland); Sedlec Ossuary Sledec, Czech Republic; Oklahoma City National Memorial \& Museum Oklahoma (USA); Museum of Genocide Victims Vilnius (Lithuania); Hoa Lo Prison Hanoi Vietnam ;Chapel of Bones Évora (Portugal) ; Island of the Dolls Mexico City (Mexico); The Suicide Forest Mount Fuji (Japan); The London Dungeon London (UK) ; Chernobyl Disaster Pripyat (Ukraine); Gallipoli Campaign Gallipoli (Turkey); Belchite Saragoça (Spain); Jack The Ripper Tours London; Hothell Porto (Portugal); Anne Frank House Prinsengracht (Amsterdam); Kigali Genocide Memorial Centre Rwanda.

\section{Methods in Dark Tourism}

'Understanding the Concept, Recognizing the Value' as an approach has been borrowed from Williams (2010) for making the title of this study. The researchers reviewed the secondary sources such as books, research articles and the research notes. Though there are various approaches of reviewing the literature, the authors followed textual narrative approach instead of following narratives synthesis (in-depth approach) which is drawn from a number of studies, both qualitative and quantitative. According to May et al.(2005; in Mair, Ritchie, \& Walter, 2014, p. 4), narrative reviews may include thematic analysis.

However, a wide range of methodological approaches have been adopted (usually reflecting the disciplinary background of the researcher). A summary of the research methods adopted in more than 100 academic paper and chapters over the 1996-2016 period is presented by Light (2017, p. 292). As he writes the most common research approach involves qualitative methods usually a combination of indepth interviews and observations of visitors' behavior. Such methods are predominantly used by 
authors with backgrounds in anthropology, sociology and human geography, mirroring a broader trend within tourism studies towards greater use of qualitative research approaches (Wilson \& Hollinshead, 2015; in Light, 2017, p. 292). There are another group of scholars with a disciplinary background of psychology, consumer behavior or business management studies that followed quantitative approach (usually questionnaire surveys with large sample). The third group of scholars has employed formal analytical techniques (such as semiotic analysis, discourse analysis, or content analysis).

\section{Review of Literatures}

In the study of dark tourism, Lennon and Foley (2000) have been popularized as a benchmark in the academic discourse of dark tourism. The book defines dark tourism as tourist interest in recent death, disaster and atrocity borne of a fundamental shift in a way which death, disaster and atrocity are being handled by those who offer associated tourism products (Lennon \& Foley, 2000, p. 3). The book highlights on the several economical, sociological, technological events upon which dark tourism sites are selected, interpreted and offered as tourism products (Lennon \& Foley, 2000, p. 3).There are several case studies on the dark tourism sites highlighted in the book which discusses on the dark tourism sites and its interpretations through media, political forces and social change.

Sharpley and Stone (2009) address several questions related to theories and concepts of dark tourism, management and implication of dark tourism and practice of dark tourism. It advances knowledge and helps to understand the phenomenon of dark tourism by providing contemporary and comprehensive analysis of dark tourism (Sharpely, 2009, p. 7). Korstanje (2011) highlighted on an emergent class of "death-seekers" who consume the spectacle of the disaster, exploring spaces of mass death and suffering. Sites that are obliterated by disasters or tragic events are recycled and visually consumed by an international audience, creating a death-seekers economy, drawing on the premise that the society of risk as imagined by post-modern sociology sets the pace to a new society: thana-capitalism. White and Frew (2013) have concentrated on visitor motivation, destination management, place interpretation from the viewpoint of demand and supply perspectives. Hooper and Lennon (2017) have dedicated to showcase the country specific case studies on Dark Tourism incidence. Recently, Stone, Hartmann, Seaton, Sharpley and White (2018) have been branded into an internationally recognized taxonomy to denote travel to sites of or sites associated with death or 'difficult heritage' within global visitor economies.

So far as dark/disaster tourism in the context of Nepal is concerned, the area which remained untouched for so long despite of the immense possibility. The discourse of dark tourism only started after 2015 earthquake. It is Hepburn (2012, 2017; in Light, 2017, p. 281) who wrote first article on dark tourism in the context of Nepal and in that paper entitled "Shades of darkness: Silence, risks, and fear among tourists and Nepalese during Nepal's civil war" published in Writing the Dark Side of Travel edited by Skinner (2012 adopted from Hepburn, 2017). It is Kužnik (2015) who proposed Nepal as a disaster tourism destination along with other different dark tourism destinations. They are Kunwar and Limbu (2015), Kunwar (2016a, 2016b) who published three articles on disaster related tourism in the postearthquake. Kunwar proposed to introduce dark tourism or thantourism as an alternative product in Langtang of Nepal. But there are many other dark tourism destinations in Nepal which are the subjects of research.

\section{Four Shades of Dark Tourism}

Sharpely (2009) attempted to offer a more holistic view of dark tourism by incorporating supply and demand factors. Specifically, he establishes a link between the site's attributes and experience sought by tourists and proposed four shades of dark tourism:

- Black tourism, describing a pure dark experience;

- Pale tourism, referring to minimal interest in death ;

- Grey tourism demand, describing visitation to dark sites motivated by fascination ;

- Grey tourism supply, which refers to sites developed to exploit death by attracting tourists with little inherent interest in the sites.

Some prominent instances are Miles (2002), distinguishing between dark, darker and darkest sites, and Stone (2006) proposed spectrum, ranging from lightest to darkest sites. Yet this approach has been criticised as leading to an increasing dilution and fuzziness of the notion of dark tourism as it arbitrarily combines markedly diverse visitor experiences (Sharpeley, 2009). 


\section{Motivation}

According to Biran, Poria \& Oren (2011), dark tourism motivations could be grouped into four factors, namely: 1. "see it to believe it" (participants' interest in seeing the site out of a need to believe that such atrocities really happened); 2. "Learning and understanding" (participants interest in being educated about Second World War and the atrocities that took place in Auschwitz); 3. "famous death tourist attractions" (general interest in sites of death, willingness to see the real site, and feel empathy with the victims); 4. "emotional heritage experience" (the desire to connect to his/her heritage and have an emotional experience). Preece and Price (2001; in Ryan \& Kohli, 2006,p.214) in a study of Port Arthur, proposed, based in interviews with visitors, three main themes of visitation, these beings a) learning ; $b$ ) historical interest and c) a fascination with the abnormal or bizarre.

Push-and-pull travel motivations play an important role for individuals in determining when and where to travel. Push factors are internal drives that motivate people to travel. They are general and nondestination-specific attributes. Crompton (1979)'s "socio-psychological motives," Dann (1981)'s "anomie" and "ego-enhancement," and IsoAhola (1982)'s "escaping" and "seeking" are examples of the push factors. In addition, push factors are not only responsible for establishing a desire to travel but also determine when and where to travel (Crompton 1979) and precede pull factors, which respond to and reinforce the push motivation (Dann, 1977). Snepenger et al. (2006) found that personal seeking, personal escape, intrapersonal seeking, and intrapersonal escape were salient intrinsic motivational push factors for tourism behavior. Likewise, Pearce and Lee (2005) assessed that escape, relaxation, relation enhancement, and self-development were core push travel motivations that do not change during travel career patterns (Rittichainuwat, 2008, p. 423). In contrast, pull factors refer to the attractiveness and specific features of the destination perceived by potential tourists that attract people to travel once the decision has been made. For example, specific attributes of a tropical beach destination, such as warm weather, a relaxed atmosphere, friendliness of the local people, and environmental quality of air, water, and soil, were important pull factors in attracting inbound tourists to Caribbean destinations (Turnbull and Uysal 1995).However, common activities easily accessible in the tourist's home environment, such as sport and entertainment, were the least important pull factors (Jamrozy \& Uysal 1994). Potential tourists consider "various," not "single," pull factors, which adequately correspond to the motivational push factors (Dann, 1981).Curiosity is an important push travel motivation for thanatourism. According to Crompton (1979), curiosity is a synonym of novelty, and a search for new experience, which results from actually seeing something rather than simply vicariously knowing about it. A sense of "ought to see" initiates the selection of a destination. Likewise, curiosity about the hidden features of punishment and extraordinary disasters pushes people to travel and pulls the curious from around the world to dark sites (Strange \& Kempa, 2003). Blom (2000) suggests four similar motivations to visit dark sites:

- tourists seek to experience something different than happens in their everyday lives;

- there is competitive demand in the tourism market to create new and unique attractions;

- tourists are searching for "catharsis" (p. 34), which can be achieved by confronting unpleasant events to which we have no personal or individual connection; and

- the media exposes us to new places and people we would not be aware of under other circumstances, thus generating interest in visiting such sites (Raine, 2013, p. 243).

Dunkley (2006, in Raine, 2013, p. 244) identifies several reasons and interests to visit dark sites, including contemplation, special interest, thrill/risk seeking, validation, authenticity, self-discovery, iconic sites, convenience, morbid curiosity, pilgrimage, remembrance and empathy. There is a particular gap in research into visitor motivations to visit burial sites specifically, which is the primary concern of this paper. The Cemetery Research Group identifies four main motivations for visiting cemeteries. These include:

- an interest in local history;

- nature lovers;

- those visiting for educative purposes; and

- people who seek passive recreation by merely walking through the site (Thomas, 2007).

\section{Seven Dark Suppliers}

Stone (2006) writes in his article about typology of dark tourism sites from a supply-oriented view. He presents "Seven Dark Suppliers" in order to construct a conceptual framework in which the supply of 
diverse and fragmented dark tourism product may be located. The order of different suppliers varies from the lightest to the darkest based on Miles' tourism paradigm presented above.

- Dark Fun Factories are entertainment focused sites which present real or fictional death and macabre events with commercial ethics. Stone brings out "Dracula Park" in Romania as an example.

- Dark Exhibitions offer products related to death often with a commemorative, educational and reflective message. Despite the conservational ethic these sites encompass some tourism infrastructure and commercial focus.

- Dark Dungeons present bygone penal and justice codes by bringing the history back through tours and acts. It is suggested that these sites may occupy the center ground of the spectrum, having both dark and light elements. Entertainment and education as a core product.

- Dark Resting Places refer mainly to cemetery sites. These revolve around a history-centric, conservational and commemorative ethic. People visit cemeteries primarily for respecting and commemorating the loved lost ones but also for exercising, relaxing and studying nature and local history.

- Dark Shrines are often situated very close to the site of death and within a short time period of the death occurring. Most Dark Shrines are non- purposeful for tourism and have very little tourism infrastructure. These sites have temporal nature and they work as an act of remembrance and respect for the recently deceased.

- Dark Conflict Sites are history-centric, war-related and originally non- purposeful in the dark tourism context. These sites essentially have an educational and commemorative focus, although, Dark Conflict Sites often have strong political ideologies on the background. Due to increased trips by tour operators, these battlefields and other war-related attractions are becoming more commercialized.

- Dark Camps of Genocide occupy the darkest age of the dark tourism spectrum. These sites represent places which have genocide, atrocity and catastrophe as the main thanatological theme.

\section{Classification of Tourists}

Based on a large-scale survey (i.e. 34000 respondents), Richards (2015; in Yousaf, Amin, \& Santos, 2018, p.199) identified three large groups of travellers: global nomads, backpackers and flashpackers. Global nomads will most likely seek contacts with local people and everyday life the destination, 'staying in local people's homes and connecting to local communication networks as well as the Internet' (Richards, 2015, p. 148; in Yousaf, Amin, \& Santos, 2018, p. 199). Backpackers typically travel together with other backpackers from home countries, and these travellers are driven by the desire to independent and alternative ways and strengthen ties or create new ties with backpacker communities, finally according to Richards (2015,p. 148), the flashpacker the most connected traveller using social media frequently and ... being more likely to mix and blur work and leisure. In the study of dark tourism, the visitors are categorized as 'blackpackers' (Podoshen, 2013), a term given to black metal fans who engage in tourism activity, who tour not only to experience live music and festival atmospheres, but to visit sites where violence associated with black metal artists and fans has occurred.

Krippendorf (1987; in Rucinska, 2016, p. 1459) said: the traveller has a mix of characteristic that are not simple to choose one category of their tourism motion. Swarbrooke (1995; in Blom, 2000) uses a classification ( of the tourists) based on the attraction. He speaks of four attraction typologies: natural sites, artifacts, facilities, and arrangements. In Burns and Holden's (1995; in Blom, 2000, p. 30) classification of tourists, the category adventurers is defined as those who 'seek', new activities, culture and people.' (Blom, 2000) adds the following those who seek and demand the unknown and the frightening which in one sense is a form of adventure.

\section{Supply, Demand and Integrated Model}

To explain the supply-demand phenomenon in dark tourism, three approaches exist. The first approach and the prevailing one is a supply perspective (Seaton \& Lennon, 2004; Stone \& Sharpley, 2008). The supply perspective adopts a descriptive understanding (Apostolakis, 2003; in Biran et al., 2011, p. 821), emphasizing the individual's presence in spaces associated with death. This line of thought has led to an eclectic collection of studies exploring a diversity of death-related sites, ranging from lightest to darkest. The supply perspective ignores the diversity of the individual's inner experience and motives, leading, in 
turn, to a simplified understanding of dark tourism, one which arbitrarily combines possibly unrelated experiences.

The second approach employs a demand-oriented perspective, where dark tourism is defined in terms of the motivation for the visit. The demand oriented approach follows the hidden assumption that the presence of tourists at death-related sites reflects at least some degree of thanatouristic motives (Slade, 2003; in Biran et al., 2011, p. 822). This approach overlooks the possibility that the reasons for visiting and the sought experiences might be completely devoid of interest in death.

The third approach, integrated supply-demand perspective, highlights the need to consider the nature of both supply and demand, narrowing the scope of dark tourism. Sharpley $(2005,2009)$, for example, calls for clarifying the links between the site's attributes and the experience sought, based on a "continuum of purpose" (Sharpley, 2009, p. 19) and recognizes four "shades" of dark tourism.

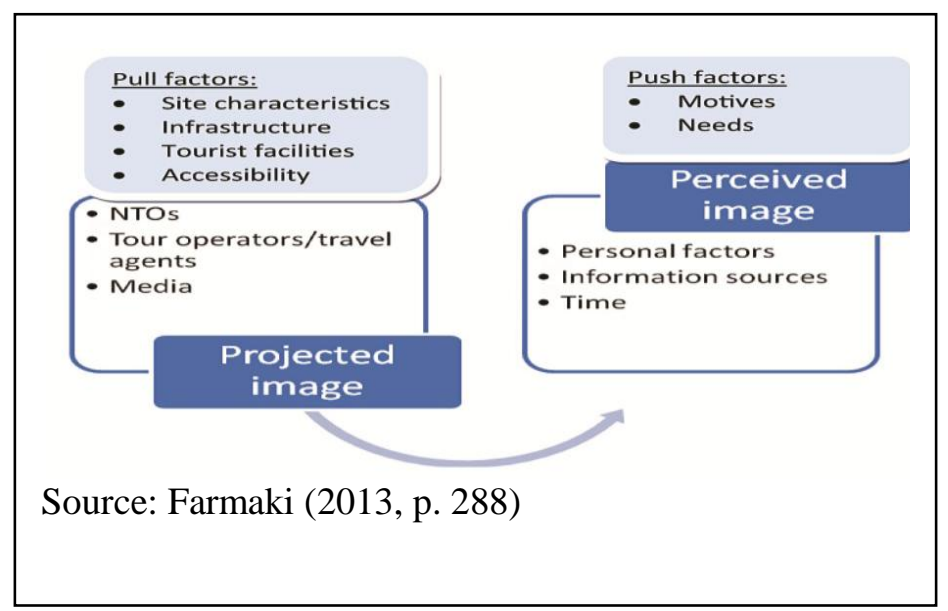

As can be seen from Figure, supply stakeholders such as national tourist organizations and tour operators are largely responsible for promoting dark sites. The projected image is also influenced by communication channels such as the media. Several factors interact to attract visitors to a site, including site-specific characteristics, the infrastructural environment, the existence of tourist facilities, and the location of a site. The projected image of the site consequently influences the perceived image held by tourists and ultimately the experience at the site. Nevertheless, a tourist's perceived image is interrelated to their motivations and intrinsic needs, which act as push factors for visiting dark sites. Similarly, several factors influencing demand and the tourist experience, including the source delivering information about the dark site (i.e. internet, tour operators, etc.), the passage of time since the dark event took place and personal factors of tourists such as nationality, sense of solidarity with the affected community and knowledge level.

\section{Dark-light Spectrum Scale}

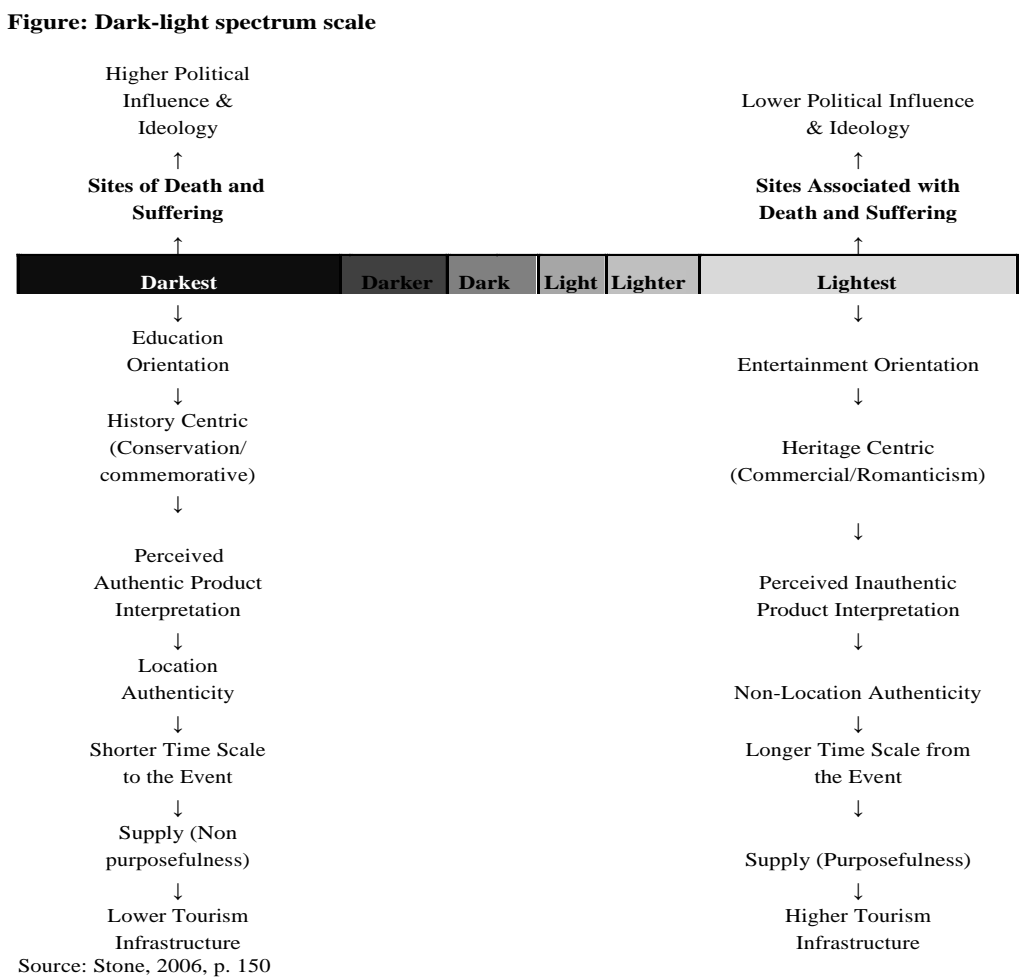

Stone (2006, p.146) points out that certain sites may be darker than others due to their characteristics, perceptions and product traits. Using his model each dark tourism product can be described and analyzed. According to darkest-lightest framework of supply (Stone), the continuum represents different levels of contact with the dark provided by dark tourism sites. On the left side of the image we can see the darkest tourism that concerns the site where death and suffering have actually occurred like Auschwitz (Poland) the world's most dark destination, symbolizing the genocide of thousands of Jews at this level the main goal to educate tourists about the place/event. On the right side of the color scale we are able to see the lightest tourism which is performed at sites merely associated with death, and therefore 


\section{0 | Journal of APF Command and Staff College}

need to possess excellent touristic infrastructure created with the intention of being attractions and entertain the tourists, one example is the Darculapark (Fonseca et al., 2016). Based on Stone's spectrum scale, cemeteries lie on the darker end of the spectrum. They are sights of death, giving educational, history-centric information and interpretations of the past. However, there is much more to cemeteries than darkness as many cemeteries around the world prove.

\section{Place Identity and Attachment}

Significant studies have been done on place interpretation of international contemporary and historic sites associated with death, disaster and atrocity and their association with tourism. According to Relph (1976: 46; in Frew \& White, 2013, p. 14), "our experiences of places are direct, complete and often unconscious". Referencing Albert Camus's writings (1965), the author presents three major components of the identity of places: the static physical settings, the activities and the meanings or symbols. The meanings of a place may stem from the physical setting and the activities, but still belong to the realm of experiences. Meanings can change from one object to the other hand, for any given object, they may vary from one individual to the other. Moreover, the feelings and identity associated with a specific place will be determined by the context (social, economic and cultural) in which people live. Thus, identity is based both on the object and the individual, and on the global culture to which they belong (Blom 2000). 'Space' and 'place' are not synonyms but belong to different perceptual categories (Borghini \& Zaghi 2006; in Frew \& White, 2013, p. 14). 'Space' is changing, moving and is no one's property. In contrast, 'place' is more or less stable, absolute, occupied and provides the possibility to experience sensations related to the area. A place is thus a tried and consumed space. Debenedetti (2004: 7; in Frew \& White, 2013, p. 14) defines place attachment as "an affective and positive bound between an individual (or a group) and its physical environment". Tilley (1994, p. 15; in Bird, 2013, p. 167) acknowledges, "the affective, emotional and symbolic significance of the landscape ... the relationship between people and the land, and the manner in which it is culturally constructed, invested with powers and significances". Low and Altman (1992: 5-6) maintain that "place refers to space that has been given meaning through personal, group or cultural processes", and that place attachment "implies that the primary target of affective bonding of people is to environmental settings themselves". The analysis of "dark resting places" (Stone 2006) focuses on cemeteries as potential objects of dark tourism.

\section{Remembrance}

Remembrance is not memory (King, 1998; in Walter, 2009, p. 47). Remembrance entails a commemoration of those whose suffering and death one may not have personally witnessed, but is not yet history. When memory is not first hand, it turns into remembrance or history, genealogy, or ancestry .... and doubtless other possibilities too (Walter, 2009, p. 47). If there is no formal way to care for the $\mathrm{dead}$, all that is left is to remember them. If a shrine is where the dead are cared for, prayed to and where guidance is sought from them, a memorial is more simply place of memory. Memories may be internal to the individual visitor, or shared within the group, but a memorial is not designed to be a place of interaction between the living and the dead-or at least, not officially.

\section{Commodification}

As Tarlow (2005) reminds us dark tourism has the commercial side making the horrors of yesterday to the business of today for this reason souvenir shops can be seen in the places of tragedy, individual's memory is replaced with collective one and those who pay their respect to the victim become the consumers. Despite the growing amount of dark tourism literature, we are presented with notable gap in terms of how marketing, branding, and destination marketing link with dark tourism sites. Site management, representation and interpretation of sites, moral issues, visitor motivations, and symbols of sites have been some of the main themes to date. Commodification has three distinct dimensions. The first is whether financial transactions of any sort should be allowable at thanatourism sites or whether they should be kept free of commercial taint. The second is, if some commercialization is allowable, who should benefit? And the third is, if commercialization is introduced: how should it be achieved in a way that does not adversely affect the site? (Seaton, 2009, p. 87).The first two may be considered together. While the introduction of, for example, an entrance fee, a gift shop or catering outlets may seem crash at a historic or religious site, it becomes less so if the revenues are used to maintain it and to employ local people. Thus, in most cases the decision to run a thanatourism site on a commercial or semi commercial basis need not be contentious if a local community supports the development and the proceeds are seen to help maintain it and/ benefit regional communities (Seaton, 2009, p. 77). 
Brown et al. (2012; in Bird, Westcott, \& Thiesen, 2018, p. 648) identify the need for the discipline and distinction of what they refer to as dark marketing. Dark marketing is defined as the application or adaptation of marketing principles and practices to domains of death, destruction and the ostensibly reprehensible' (Brown et al., 2013, p. 198). The financial model is geared toward the overall success and the profitability of the attraction. This involves the development of a darsumer market, a term used to describe consumers of dark tourism products that commercialized operators attempt to retain through marketing processes (Robinson \& Dale, 2009b), this includes promotional activities and relationship building with costumers to encourage brand loyalty and repeat visits.

\section{Niche Tourism}

A special interest or niche tourist's motivation is either to indulge in or to develop a new interest in a new or familiar location. Special interest tourism can be either the focus of the whole holiday or a way to spend one or two days during a holiday. Dark tourism is also recognized as a special interest form of tourism appealing to those keen to visit sites or attractions associated with the dark side of human nature and often tied to death, atrocity or tragic events of the past (Asworth \& Hartmann, 2005; Lennon \& Foley, 2000; Kuznik, 2015, p. 324). The themes of interest military history and visiting battle fields can be also mentioned as an example (Swarbrooke \& Horner, 2007, 37-38 ; in Titta, 2010,p. 7; Novelli, 2005). Niche tourism, at one end of the spectrum, can be defined as breaking down into still relatively large market sectors (macro-niches-i.e. cultural tourism, rural tourism, sport tourism etc.), each capable of further (micro-niches-i.e. geo-tourism, gastronomy tourism, cycling tourism etc.). At the other end of the spectrum, niche tourism is focused on very precise small markets that would be difficult to split further but as well as niche tourism based around what tourist's do, there is also a geographical dimension by which location of highly specific offers are able to establish themselves as niche destinations (Robinson \& Novelli, 2005, pp, 5-6). While describing about dark tourism, Tarlow (2005,p. 52) writes, "there is a blending of past and future, creator and observer, when perpetrators become producers of the attraction- the niche product and those who remember the victims become the consumers" to which Robinson and Dale (2009 b, p. 213) darsumer as mentioned earlier.

\section{Edutainment}

The dead may be encountered for educational purposes. Educational visits to the dead, whether in the classroom through books or at heritage sites through educational tourism, are the basis of the teaching of history. Sometimes the dead are physically present, as in exhibitions of mummies and bog bodies. The exhibition, like all popular yet purportedly serious exhibitions, museums and heritage sites, and indeed like comparable television documentaries, is edutainment. The dead, like much else from the past, are used to educate and entertain today's massed- as they were too in $18^{\text {th }}$-century public executions (Walter, 2009, p. 48). To which Roberts (2018) Dale and Robinson (2011) called 'dartainment', which identifies both dark attractions that attempt to entertain (Robinson\& Dale, 2009 b; in Dale \&Robinson, 2011, p. 213).

\section{Authenticity}

Authenticity (see in detail MacCannell, 1976; Olsen, 2002; Wang, 1999) can be defined based on five perspectives: objective/essentialist, constructivist, negotiated, existentialist, and theoplacity. The essentialist (also referred to as objective by extant literature) notion refers to being original and genuine, such as being manufactured in the place of origin or made/produced locally by ethnic communities, and pristineness (Chhabra, 2010; in Chhabra, Lee, Zhao, \& Scott, 2013, p. 147). The constructivist viewpoint advocates the notion that all judgments are colored by the prevailing market forces and environments. The readings based on this perspective relate to completely commodified forms of authenticity such as hyper-real settings and carefully constructed pseudo-backstages (MacCannell, 1992; in Chhabra et al., 2013, p. 147).

Next, the negotiated school of thought advocates a trade-off between the (1) essentialist and constructivist and (2) existentialist and essentialist theories. The essentialist/constructivist negotiation points to a co-creation of authenticity based by the suppliers and the consumers. It argues that it is possible to sustain elements of object authenticity by carefully embracing change and market demand. This process can, therefore, serve a useful purpose of mapping a middle path. Theoplacity, the second negotiated position version of negotiation argues that consumers can have an optimal and exhilarating experience in objectively authentic settings. The last notion of authenticity argues that personal meanings 


\section{2 | Journal of APF Command and Staff College}

and state of mind dictate anoptimal authentic experience and refers to terms such as 'self discovery', 'being true to oneself' (Steiner \& Reisinger 2006, p. 299; in Chhabra et al., 2013, pp. 147-148) and exalted living within tourist moments (Wang, 1999). MacCannell (1976) argues in his seminal work that the modern tourist recognises the inauthenticity of contemporary social life and thus becomes a secular pilgrim seeking the authentic: 'sightseeing is a kind of collective striving for a transcendence of the modern totality, a way of attempting to overcome the discontinuity of modernity' (MacCannell, 1976). For MacCannell, however, the tourist's quest for authenticity is doomed to failure; authenticity is inevitably 'staged' for tourists (MacCannell, 1973; in Sharpley \& Stone, 2009, p. 116). It has been suggested that academic attention should be focused not on the degree of authenticity of particular tourist experiences, but on the process of 'authentication' of tourist sites and attractions - that is, how and why they are deemed authentic (Xie \& Wall, 2008; in Sharpley \& Stone, 2009, p. 116).

In the study of dark tourism, Sharpley and Stone (2009) follow MacCannell's concept and they write ... the tourist as pilgrim seeking to challenge the discontinuity of modernity is fundamental to understanding the need for an emotive, affective or authentic component in dark heritage interpretation. The consumption of dark tourism sites or attractions may be driven by the need not only to remember or commemorate the death/ suffering of others, but also to confront and contextualize it within the individual tourist's own social world. Thus, Sharpley and Stone emphasis to show the link between the consumption of experience of the site and its subsequent contribution to identity creation. As considered elsewhere, the consumption of goods and services in general, and of tourism experiences in particular, is related to their social significance (Munt, 1994; in Sharpley \& Stone, 2009, p. 117).

\section{Interpretation}

'Interpretation is an essential component of visitor experiences at attractions' (Moscardo \& Ballantyne, 2008, p. 237; in Sharpley \& Stone, 2009, p. 113). It provided the link between an attraction and its visitors it is the process by which a place, an event, history, a building, a collection of items or more generally what may be referred to as heritage is accorded meaning which is then communicated by one means or another to the visitor. Interpretation plays a key role in this process, acting as a 'filter' to emotional responses to a dark site or attraction, On the one hand, appropriate interpretation may enhance the visitor experience and fulfil the need for understanding and meaning. As Tilden (1977, p. 9; in Sharpley \& Stone, 2009, p. 114) suggests in his first principle of interpretation, 'any interpretation that doesn't somehow relate what is being displayed or described to something within the personality or experience of the visitor will be sterile'. For Tilden, interpretation is ' an educational activity which aims to reveal meanings and relationships through the use of original objects by firsthand experience, and by illustrative media, rather than simply to communicate factual information (Tilden, 1977, p. 8; in Sharpley \& Stone, p. 114).As a management 'tool', interpretation has also benefited, of course, from technological advances as the more traditional forms of interpretation such as guided tours, information signs and panels, visitor center and live performances are being augmented by, for example, self-directed tours using pre-downloaded mp3-formataudio tours, like those offered by English Heritage for some of their historic sites (see www.english-heritage.org.uk) (Sharpley \& Stone, 2009,p. 114).On the other hand, interpretation that misleads, trivializes, commercializes the experiences may act as a barrier.

\section{Postmodernism}

Much of the literature on dark tourism invariably defines the phenomenon in the context of postmodernism. Therefore, it is necessary to understand the origins and chronology of post-modernism in order to fully comprehend the role dark tourism plays in today's society. A starting point is modernism, the movement from which post-modernism emerged. Many more are human accidents provoked by the very technology that we celebrate (Riding, 2003). The sociological discourse of postmodern tourism consists of two theoretical frameworks-"simulational" and the "other" postmodern tourism (Munt, 1994; in Uriely, 1997, P. 983). The simulational line of scholarship is focused around the analysis of "hyperreal" experiences and refers to simulated theme parks and other contrived attractions as typical postmodern environments (Baudrillard, 1983; Eco, 1986; Featherstone, 1991 Lash \& Urry, 1994; Pretcs, 1995; in Uriely, 1997, p. 983). Conceptualizations of the "other" Postmodern tourism stress the serch for the "real" and point to the growing appeal of the "natural" and the countryside as postmodern expressions (Barrett, 1989; Munt, 1994; Poon, 1989; Urry, 1990; in Uriely, 1997, P. 183). It seems as though the distinction between the "simulational" and the "other" dimensions of postmodern tourism follows the polarity noted among the earlier theories of modern tourism. While the "simulational" post modern 
tourism follows Boorstin's notion of "pseudo-events" (1964; in Uriely, 1997) the "other" postmodern tourism follows McConnell's (1976) argument regarding the quest for authenticity. Uriely's (1997) analysis suggests that unlike the polemic, authoritative, and homogenizing discourse of modern tourism, the discourse of postmodern tourism consists of compromising statements and stresses the multiplicity of tourist experiences. 'The other' typically meant 'People not like us', as Hawthorn's definition suggests:

...to characterize a person, group or individual as 'other' is to place them outside the system of normality or convention to which one oneself (Hawthorn, 1994, p. 141; in Seaton, 2009, p. 76).

Othering is a process that happens whenever one group first encounters an unfamiliar one (Seaton, 2009, p. 78).

\begin{abstract}
..., the Other may be a desire for difference that takes them 'out of ourselves', a desire for a sabbatical from the everyday self and mundane society, for others, the Other is what always brings them back, an anti-structure that serves, in opposition to its perceived wrongness, to keep them right in their own world (Seaton, 2009, p. 83).To these two may be added a third assertion: that the Otherness of death is the most powerful of all Others and one which, as the unique element in thanatourism, distinguishes from all other kinds of tourism (Seaton, 2009, p. 83).
\end{abstract}

\title{
Theorizing Dark Tourism
}

Some conceptualisations of dark tourism do not involve death at all. Biran and Poria (2012) propose that dark tourism should be defined in terms of deviance (specifically "negative deviance") that is participation in activities which are shameful or socially condemned. This approach effectively equates dark tourism with dark leisure (See also Yan et al., 2016; in Light, 2017, p. 281), but also implies that dark tourism need not have any association with death. Another conceptualisation draws on the notion of tourism in darkness (Hepburn, 2012, p. 122; in Light, 2017, p. 181) to argue that places of socio-political danger" represent dark (or forbidden destinations) so that visit to such places constitute a form of dark tourism (Buda \& McIntosh, 2013; in Light, 2017). Similarly Buda \& Shim (2015, 9. 4; in Light, 2017) argue that tourists visit North Korea from a desire for "dark, forbidden and possibly dangerous activities and locations". However, Connell (2017) claims that visiting North Korea represent a form of "moral political tourism" (p. 6). There is a growing body of work that considers visits to dangerous places and conflict zones from the perspective of dark tourism (Buda, 2015a; in Light, 2017) which means that the boundaries between dark tourism and adventure tourism are increasingly blurred.

Traditional theories of tourism motivation have been limited use in explaining the consumption of dark tourism or thanatourism. By far the most detailed and sophisticated theorization of dark tourism consumption is the 'mortality mediation' model proposed by Stone \& Sharpley (Stone, 2009a, 2009b, 2009c, 2011b, 2011c, 2012a, 2012b, 2013a; Stone \& Sharpley, 2008, 2014; Walter, 2009; In Light, 2017, p. 288) which draws upon notions of thanatopsis and the sociology of death to understand visits to places associated with death and suffering. The mortality mediation thesis argues that death has been sequestrated (removed from the public sphere) in contemporary societies, leaving individuals isolated from the realities of death because individuals may feel a sense of anxiety and vulnerability about death in ways that can challenge senses if self. At the same time there has been marked increase in the representation and recreation of death within popular culture so that 'absent death' has become present in new ways i.e religion, body world museums. Visiting places associated with death through dark tourism prospect enables individuals to encounter and negotiate death in situations that do not involve terror or dread. It presents setting for individuals to satisfy their curiosity and fascination about death and to confront the inevitability of their own death through gazing upon the death of significant others (Stone, 2009a). Stone (2012 b) recognizes that a visit to a dark site is an opportunity to accumulate "death capital" (Stone, 2011 b, p. 698).

Dark tourism is thus conceived as a non-religious mediating institution between the living and the dead, offering an opportunity of thanatopic contemplation in face of inevitable (and meaningless) of death. Stone (2006) quotes Lennon and Foley's (2006, p.149) assertion that dark tourism is primarily western phenomenon. In this regard, Cohen (2018, p.157) further clarifies that once tourism was also considered Western phenomenon but now it universalized that tourism is globalised. Then, question can be asked do dark tourism phenomena exit non-Western emergent world reason ... Cohen suggests that the Stone's paradigmatic approach could thus be broadened into comparative conceptual framework... The crucial point of Stone's paradigmatic approach is the modern secular "theology" with life and death. For present purposes this can be concisely presented in a few basic premises:

- Human life is a once only event; 
- Death is an inevitable terminal point of individual life, the point of the ontological cessation of individual extreme;

- There is no afterlife either as eternal life or rebirth;

- Hence, death is meaningless; there is no hope.

Mortality mediation is a complex and challenging theory. It suggests that visitors to sites associated with death and suffering may reflect upon (and contemplate) death in a multitude of ways (which will often be incidental, unintended, or implicit) and some visitors may not engage in such reflection at all. The nature of reflection will also vary according to the social and cultural background of visitors. Best and Kellner (2001, p. 16) note that present-day society 'is in the midst of a tempestuous period of transition and metamorphosis, propelled principally by transmutations in science, technology, and capitalism' and, perhaps more recently, by geopolitical turmoil in a post 9/11 world. Hence, that the 'secularisation of life should be accompanied by the secularization of death should come as no surprise: to live in the modern is to die in it also' (Tercier, 2005, p. 13).

\section{Role of Media}

'Disasters are unusual, dramatic, and often have great impact upon people's lives. This combination makes disasters newsworthy and creates the expectation that news outlets, which are driven by commercial imperatives will report them' (van Belle, 2000, 250; in Sharpley \& Wright, 2018, p. 335). In other words, as Cockburn (2011; in Sharpley \& Wright, 2018, p. 335) observes "the media generally assume the news of war, crime, and natural disasters will always win an audience", hence the well known adage in journalism - 'if it bleeds it leads' (Sharpley \& Wright, 2018, p. 335). In other words, once a disaster has been publicized, it becomes an attraction to those who, for whatever reason, wish to travel to gaze upon it (Rojek, 1997; in Sharpley \& Wright, 2018, p. 336). Seaton (1996; in Stone, 2006, p. 150) suggest that the role of the media has been central to this growth in tourism to sites, attractions and exhibitions associated with death, principally through increasing the geographical specificity of murder and violent death and, more recently through global communication technology that televises events almost as they happen into people's 'living rooms' around the world (Seaton \& Lenon, 2004; in Stone, 2006, p.150).

Media Interest is growing: but a fundamental question with respect to dark tourism remain unanswered, whether it is actually possible or justifiable to categorize collectively the experience of sites or attractions that are associated with death or suffering as 'dark tourism'. Since the collective umbrella term includes a variety of sites, attractions and experiences its meaning has been diluted and fuzzy. More specifically, it remains unclear whether dark tourism is tourist-demand or attraction-supply driven as a (post) modern propensity for 'mourning sickness' (West, 2004).

The media generally provide the first impressions of a place or origin. In morbid tourism the media plays a crucial role by focusing on describing places, regions, events and phenomena, the media create an image or symbol, which produces associations in the individual. These images or symbols function as a kind of 'clothes hanger' on which the individual can hang their experience and feelings (Blom, 2000). The news media love a disaster (Tarlow, 2011; in Sharpley \& Wright, 2018, p. 335). 'Disasters are unusual, dramatic and often have great impact on people's lives. This combination makes disaster newsworthy and creates the expectation that news outlets which are driven by commercial imperatives, will report them' (van Belle, 2000, p. 50; in Sharpley \& Wright, 2018, p. 335). In other words, as Cockborn (2011; in Sharpley \& Wright, 2018) observes, 'the media generally assume that news of war crime and natural disasters, will always an audience', hence the well-known adage in journalism- 'if it bleeds, it leads'. Moreover many of the myths are created by the media industry more generally ; books and films, for example have used the crucible of disaster as a setting for the espousal of tales of tragedy, chaos, suffering, love, and courage acted out by a menagerie of heroes, villains, fools, cowards, and scoundrels (Wenger, 1985, p.2; in Sharpley \& Wright, 2018,p.336), such tales being the source of myths that persists both in disaster reporting and public conscientiousness (Sharpley \& Wright, 2018, p. 336)....once a disaster has been published, it becomes an attraction to those who, for whatever reason wish to travel to gaze upon it (Rojek,1997; in Sharpley \& Wright, 2018, p. 336).

\section{Emotion and Experience}

Emotion can be defined as felt short-lived responses to external stimuli (Reeve, 2008; in Asworth \& Isaac, 2015, p. 4). According to Tarlow (2005), there are four basic emotions which interact on a dark 
tourist psychological state: insecurity, gratitude, humility and superiority. Visiting a dark attraction can raise multiple feelings as well as dark tourism can be seen in various ways. Plutchik (1980; in Asworth \& Isaac, 2015, p. 4) described eight primary emotions namely: joy, sadness, acceptance, disgust, fear, anger, surprise and anticipation. He categorized this into positive (joy, acceptance, anticipation and surprise) and negative (anger, fear, disgust and sadness) emotions. Nawijn and Fricke (2015; in Asworth \& Isaac, 2015 , p. 4) expanded the list to ten, divided into five positive (relief, pleasure, fascination, joy, positive, surprise) and five negative (anger, sadness, scare, shock, negative surprise). Asworth and Isaac have listed emotions most usually experienced at dark tourism sites that include curiosity, shame, empathetic grief, psychotic disturbance, offence/ anger and fear. Emotional experiences undoubtedly vary over time and between individuals an individual visitor, whose visit was motivated by a number of reasons, may then experience, during their visit, a spectrum of emotions from curiosity about the unusual and unfamiliar through empathetic grief and sorrow to offence and anger wherever directed.

An experience is something that happens to somebody because of exposure to an external circumstance. The study of the experience as dark leads to a focus upon human sentiment as a response to this experience. Few would disagree with a statement such as, 'a visit to a dark tourism requires emotion on the part of the visitor' (Miles, 2002, p. 175). The meaning of 'experience' is essentially synonymous with 'psychological outcome' to bespeak the specific response that is supplied by dark tourism sites, frequently referring to emotion and cognition (Shin, Jaakson \& Kim, 2001; in Yan et al., 2016, p. 110). As Desmond (1999; in Robb, 2009, p. 56) has argued effectively the notion of touristic experience should be expanded to include a wide range of embodied aspects.

Desmond agrees that tourism is important in generating knowledge, where in an event, history, or a famous person's life and death can be internalized and inscribed within the being of the visitor. At the same time, in the case of dark tourism, this experience makes the suffering of the other just that -radically other (Robb, 2009, p. 56).Dark tourism provides not only an emotional (Cheal \& Griffin, 2013; Mowatt \& Chancellor, 2011; Podoshen, 2013; Rittichainuwat, 2008; Stone, 2012; in Yan et al., 2016, p. 110) or cognitive space (Stone, 2012; Yan et al., 2016, p. 110) through which tourists can acquire 'dark' experiences that differ from routine experiences but also a physical space through which one can relate desired psychological outcomes with actual psychological outcomes (Shin et al., 2001). Thus, in dark tourism, the tourist host (i.e., tourist) and object (i.e., destination) are distinguished as follows:

- Dark tourism is a psychological consumption process that offers tourists desired psychological outcomes and actual psychological outcomes to satisfy tourists' emotional demands.

- Dark tourism is a symbolic consumption process that supplies emotional and cognitive experiences to tourists who have an interactive relationship with a dark tourism product, including either man-made or natural disaster destinations.

\section{Tourist Experience}

In the age of postmodernity, the experience of consumers plays an increasingly important role in economic and social life. In social science literature on the tourist experience, most researchers focus on the experience in sharp contrast to the daily experience. The tourist experience is thus understood as the "pure", "net" or "peak" experience, usually derived from the attractions, rather than "mixed", "gross" or "supporting" experience such as eating, sleeping and so on. The relationship between the two (Peak experience and daily experience) can thus characteristically summarized by a series of "opposition" between the daily and the peak experiences, such as "the ordinary" vs. "the extraordinary", "routine" vs. "usual", the "familiar" vs. "novel", "the profane" vs. "the sacred" and so on (Quan \& Wang, 2004, p. 300). Those experiences that are regarded as the extension of the daily experience to the tourist journey, such as the experience of accommodation and transport, are mostly either ignored or taken for granted (Quan \& Wang, 2004, p. 297).

There are two general approaches to the study of the tourist experience, namely, the social science approach and the marketing/management approach. This refers to the experience of the attractions that constitute the major motivations to tourism. The latter treats the tourist experience as supporting consumer experience, which refers to the experiences of gratifying basic consumer needs on the journey, such as eating, sleeping and transport, which do not constitute the major motivations to tourism whereas the former regards the tourist experience as peak experience being in sharp contrast to the daily experience. Both approaches catch important and essential dimensions of the tourist experience, which is 


\section{6 | Journal of APF Command and Staff College}

conceptually different, but constitute an organic whole through structural model such as extension intensification - contrast, which helps to better understand. Such a structural model clarifies the loci and the structure of the components of "familiarity" and "novelty" in the total tourist experience and has practical implications for tourism management (Quan \& Wang, 2004, p. 301).

\section{Ethical Dilemma of Dark Tourism}

Significant debate surrounds on whether is it ethical to develop, promote or offer the dark sites for touristic consumption or not i.e. viewing platform at Ground Zero, enabling voyeuristic visitors to stand alongside those mourning the loss of loved ones (Lisle, 2004). The rights of those whose death is commoditized through dark tourism represent an important ethical dimension deserving consideration. Dark tourism in some cases, result in the transformation of violence into one more attraction, wedged in between more typical tourist activities. When atrocity becomes a recreational attraction, visitors are themselves inflicting further violence as they search out unique and authentic experiences. Ethically one must question whether tours undertaken in the name of social justice or global awareness are actually experienced as such or whether they might instead work to mask the recreational, voyeuristic allure of violence. At times dark tourism can produce "recreational grief" (West, 2004, p. 11; in Robb, 2009, p. 55) a form of grief in which mourning the deaths or afflictions of others becomes an enjoyable past time. In terms of supply- there has been increasing number of people keen to promote or profit from 'dark' events as tourist attractions. At the same time, there is evidence of greater willingness on the part of tourist to visit dark attractions.

\section{Criticism}

Although dark tourism research prompts important discussions about the intersections of touring and death, Sharpley (2005: 216) rightly notes that 'dark tourism literature remains eclectic and theoretically fragile, raising more questions than its answers'. Likewise, Keil (2005: 481; in Bowman \& Pezzullo, 2009 , p. 188) argues that '[the dark tourism] phenomenon has so far been inadequately described, and lacks a theoretical relationship to wider studies of violence and by-standing'. Even so, many who have questioned the term thus far have exacerbated the problem by trying to identify different 'shades' of or umbrella terms for 'darkness' without challenging the term itself (e.g. Miles, 2002; Strange \& Kempa, 2003; Sharpley, 2005: 224-26; Stone, 2006; Bowman \& Pezzullo, 2009, p. 188).Lennon and Foley (2000: 11) offer no explanation for their choice of terms and state that they 'do not wish to enter into any philosophical debates' over its use. However, the negative valence of the term is unmistakable in western cultures: 'dark' is understood as a place devoid of light. In tourist studies, we might assume the label serves as a contrast to the trifecta of Sun, Surf, and Sex that many narrowly associate with a holiday vacation. 'Dark' also could allude to the 'dark deeds' (e.g. genocide, assassination, murder, war) that animate such sites and the 'dark mood' or morose tones such events might invite. Lennon and Foley link dark tourism with the contemporary (post-World War I) historical period and there is perhaps a suggestion that dark tourism is a sign that the postmodern, post-Enlightenment world augurs a new 'Dark Ages'. Finally, we find in the range of connotations of 'dark' a suggestion that such sites are devoid of actors and performances: 'The theatre has gone dark'. In contrast, we suggest that remembering and attending to the performances at sites associated with death might undo or at least help trouble the troubling nomenclature of 'dark tourism' to reclaim space for different approaches (Bowman \& Pezzullo, 2009, p. 188).

\section{Conclusion}

For Dann and Seaton (2001; in Ryan \& Kohli, 2006, p. 214), any travel to sites associated with death, disaster, acts of violence, tragedy, scenes of death and crimes against humanity may be defined as "dark tourism". Increasing academic attention has been paid over the last two decades to the phenomenon of dark tourism in general (e.g., Johnston \& Mandelartz, 2015; Lennon \& Foley, 2000; Sharpley \& Stone 2009; Stone, 2013), including disasters (Coats \& Ferguson, 2013; Gould \& Lewis, 2007) and motives for participating in dark tourism in particular (e.g., Isaac \& Cakmak, 2014; Raine, 2013; Seaton, 1996; in Sharpley \& Wright, 2018, p. 337). Though this phenomenon has been sufficiently criticized by number of scholars, it became popular not only in the West but also it is gradually extending towards other parts of the world, to justify this statement. The study of dark tourism is both justifiable and important for a number of reasons... all dark tourism sites or attractions require effective and appropriate development, management, interpretation and promotion. These in turn require a fuller understanding of the 
phenomenon of dark tourism within social, cultural, historical and political context (Sharpley, 2009, pp. 7-8). Dark tourism is both supply and demand driven, and it is important to understand both in order to gain a fuller understanding of the phenomenon of dark tourism (Raine, 2013, p. 243). The values of dark tourism are four shades of dark tourism; dark tourism spectrum framework; and seven dark suppliers' categorization with varying degree of darkness. Tourism and death may seem an odd conjunction. This entered tourism discourse as thanatourism in 1996 and dark tourism in 2000.

Cohen (2018, p. 168; Cohen \& Cohen 2015b) distinguishes between two major thanatourist sites in Asia. Firstly, memorial sites to popular non-kin deceased person and, secondly, memorials of war, atrocities and disaster. The philosophy of death has been distinguished between theology (Western regions) and soteriology (Asian regions) (Cohen, 2018, P. 168). Dark tourism has been characterized by contemplation of death. Dark tourism brings to life the history of the tragedies once occurred, reason why, the innumerable sites/attraction that it offers; permit the individuals to have further contact, in a safe ambience with death (Fonseca et al., 2016, pp. 3-4). Dark tourism as an alternative type of tourism is gaining and increasingly interest and needs to be designed more profoundly. Dark tourism cannot be perceived as an expression of tourist demand only, but rather needs to be considered in conjunction with tourism supply (Fonseca et al., 2016, pp. 3-4). When this discourse came in existence in 1990s, many people from different countries were encouraged to visit battlefields, celebrity death sites, graveyards, cemeteries, atrocity and disaster sites, murder location, memorials, museums of war, torture, horror and conflicting zones. The consensus between the literature researchers is that dark tourism has a typology depending on the visitors' motivations and sites. Though the term dark denotes devoid of light, dark tourism as a new tourism product tends to provide awareness, education and entertainment on several cases of history and heritage, tourism and tragedies. Overall the prime focus of dark tourism is grief after death caused by fatality of 'Others' (Seaton,2009). Therefore, scholars of various disciplines, in course of studying dark tourism brought many different concepts such as " sensation sites" (Rojek, 1997), "repressed sadism" (Krostanje, 2018), "sadist spectacle" (Blom, 2000), "dartainment" (Roberts, 2018), "deathscapes" (Maddrell \& Sidaway, 2012; in Yan et al., 2016, p. 110) "memorialscapes" (Fridrich, Stone, \& Rukesha, 2018), "blackpackers" (Podoshen, 2013), "recreational grief" (West, 2004; in Robb, 2009, p. 54), "mortality mediation" (Stone \& Sharpley 2012; Walter, 2009), " thanacapitalism" (Krostanje, 2017), "everyday dark" (Hepburn, 2017). Multidisciplinary and Postdisciplinary approaches have become major methodological concern in dark tourism studies. Until 2016, Light (2017) has shown that 58 out 139 studies followed qualitative research methodology in the study of dark tourism. Much of the literatures on dark tourism invariably defines the phenomenon in the context of post-modernism. Overall, dark tourism has been promoted as commercialization of grief and commodification of death which has become the centre of attraction. This study identifies several scopes of dark tourism/thanatology tourism in Nepal.

\section{References}

Ashworth, G. J. \& Isaac, R.K. (2015). Have we illuminated the dark? Shifting perspectives on dark tourism.Tourism Recreation Research,1-17.

Biran, A., Poria, Y., \& Oren, G. (2011).Sought experiences at (dark) heritage sites.Annals of Tourism Research, 38(3), 820-841.

Bird, G., Westcott, M., \&Thiesen, N. (2018). Marketing dark heritage: Building brands, myth-making and social marketing. In Stone,P.R., Hartmann, R., Seaton, T., Sharpley, R. \& White, L.(Eds. )The Palgrave Handbook of Dark Tourism,(pp.645-665), Palgrave macmillan

Bird, G.R. (2013). Place identities in the Normandy landscape of war: Touring the Canadian sites of memory. In White, L. \&Frew, E. (Eds.) Dark Tourism and Place Identity :Managing and Interpreting Dark Places (pp.167-185), London: Routledge.

Blom, T. (2000).Morbid tourism - a postmodern market niche with an example from Althorp.NorskGeografiskTidsskrift - Norwegian Journal of Geography, 54(1), 29-36.

Bowman, M. S. \& Pezzullo, P. C. (2009). What's so "Dark" about "Dark Tourism"?: Death, Tours, and Performance. Tourist Studies, 9(3), 187-202.

Byran, A.\& Hyde,K.F.(2013). Guest Editorial: New perspectives on dark tourism.Internationa Journal of Culture, Tourism and Hospitality Research, 7(3),191-198.

Causevic, S. \& Lynch, P. (2011). Phoenix tourism: Post-conflict tourism role. Annals of Tourism Research, 38(3), 780-800. 


\section{8 | Journal of APF Command and Staff College}

Cohen, E. \& Cohen ,S.A.(2015b). Beyond Eurocentrism in tourism: A paradigm shift to mobilities. Tourism Recreation Research, 40(2), 157-168.

Cohen, E. (2018). Thanatourism: A comparative approach. In Stone, P.R., Hartmann, R., Seaton, T., Sharpley, R., \& White, L. (Eds.). The Palgrave Handbook of Dark Tourism Studies(pp.157-171), Palgrave Macmillan , U.K.

Coles, T. Hall, C. M., \& Duval, D.T. (2009). Post-disciplinary tourism. In Tribe, J. (Ed.) Philosophical Issues in Tourism (pp.82-100), Bristol: Channel View Publications.

Dale, C. \& Robinson, N. (2011).Dark Tourism. In Robinson, P, Heitmann, S. \&Dieke, P.(Eds.) Research Themes for Tourism (pp.205-217), Wallingford : CABI.

Farmaki, A. (2013). Dark tourism revisited: A supply/demand conceptualization. International Journal of Culture, Tourism and Hospitality Research, 7(3), 281-292.

Foley, M. \& Lennon, J. (1996). Editorial: Heart of darkness. International Journal of Heritage Studies, 2(4),195-197.

Fonseca, A.P., Seabra, C.\&Silva.C.(2016). Dark tourism: Concepts, typologies and sites. Journal of Research and Hospitality, S2,1-6.

Fridrich, M., Stone, P.R., \& Rukesha, P. (2018). Dark tourism, difficult heritage, and memorialization : A case of the Rwandan genocide. In Stone, P.R., Hartmann, R., Seaton, T., Sharpley, R., \& White, L. (Eds.) The Palgrave Handbook of Dark Tourism Studies(pp.261-289), Palgrave Macmillan, U.K.

Hepburn,S.J. (2017).Everyday darkness and catastrophic events: Riding Nepal's buses through peace,war, and an earthquake. In Hooper, G.\& Lennon.J.J.(Eds.)Dark Tourism : Practice and Interpretation(pp.147159), London : Routledge.

Hooper, G. \& Lennon, J. J. (Eds.) (2017). Dark tourism: Practice and interpretation, London :Routledge.

Knudsen, B. T. (2017).Experiencing dark heritage live. In Hooper, G. and Lennon,J.J (Eds.)Dark Tourism : Practice and Interpretation (pp.174-186), London : Routledge.

Korstanje, M.E. \& Ivanov, S.(2012). Tourism as a form of new psychological resilience : the inception of dark tourism. Cultur,56-71.

Korstanje, M.E. (2011). Detaching the elementary forms of dark-tourism.Anatolia:An International Journal of Tourism and Hospitality Research,22,424-427.

Krostanje, M.E.(2017). The Rise of Thana-Capitalism and Tourism, London: Routledge.

Kunwar, R.R. \&Limbu, B.(2015). Tourism and earthquake : A case study of Nepal and Turkey. NATTA Souvenir, Kathmandu.

Kunwar, R.R. (2016a). Tourism crisis and disaster management.The Gaze Journal of Tourism and Hospitality, 7(1), 1-36.

Kunwar, R. R. (2016b).Tourism and the natural disaster : A study of Nepal's earthquake. Voice of Himalaya, Kathmandu : Nepal Mountain Academy.

Kužnik, L. (2015). Typology of dark tourism heritage with its implications on Slovenian future dark tourism products. $R S C, 7(3), 318-348$.

Light,D.(2017).Progress in dark tourism and thana-tourism research an uneasy relationship with heritage tourism.Tourism Management: 61,275-301.

MacCannell, D. (1976). The Tourist: A New Theory of the Leisure Class, London: Macmillan.

Miles, W.F.S. (2002). Auschwitz: museum interpretation and darker tourism. Annals of Tourism Research, 29(4), 1175-8.

Olsen, K. (2002). Authenticity as a concept in tourism research: The social organization of the experience of authenticity. Tourist Studies 2(2), 159-182.

Podoshen, J.S.(2013). Dark tourism motivations, simulation, emotional contagion and topographic comparision.Tourism Management, 35,263-271.

Quan, S., \& Wang, N. (2004). Towards a structural model of tourist experience: An illustration from food experience in tourism. Tourism Management, 25, 297-305.

Raine, R. (2013). A dark tourist spectrum.International Journal of Culture, Tourism and Hospitality Research, 7(3), 242-256.

Rittichainuwat, B., Nelson, R., \& Rahmafitria, F. (2018).Applying the perceived probability of risk and bias toward optimism: Implications for travel decisions in the face of natural disasters.Tourism Management, 66, 221-232. 
Robb, E.M.(2009).Violence and recreation: Vacationing in the realm of dark tourism. Anthropology and Humanism, 34(1), 51-60.

Roberts, C. (2018). Education the (dark) masses: dark tourism and sensemaking. In Stone, P.R., Hartmann, R., Seaton, T., Sharpley, R., \& White, L. (Eds.)The Palgrave Handbook of Dark Tourism Studies(pp.606637), Palgrave Macmillan, U.K.

Robinson, M. \& Novelli, M. (2005). Niche tourism:An introduction. In Novelli, M. (Ed.) Niche Tourism : Contemporary Issues, Trends and Cases.(1-11).

Rucińska, D. (2016). Natural disaster tourism as a type of dark tourism.International Journal ofHumanities and Social Science, 10(5)1458-1462.

Ryan, C.\&Kohli, R.(2006). The Buried Village, New Zealand- An example of dark tourism? Asia Pacific Journal of Tourism Research, 11(3),211-226.

Seaton, T. (2009). Purposeful otherness: Approaches to the management of thanatourism. In Sharpley, R. \& Stone, P.R. (Eds.).The Darker Side of Travel (pp. 75-108). Bristol: Channel View Publications.

Sharpley, R. \& Wright, D. (2018). Disasters and disaster tourism; The role of the media. In Stone, P.R., Hartmann, R., Seaton, T., Sharpley, R. \& White, L. (Eds.) The Palgrave Handbook of Dark Tourism Studies (pp.335-354), Palgrave macmillan.

Sharpley, R. (2009). Shedding light on dark tourism. In Sharpley, R. \& Stone, P.R. (Eds.) The Darker Side of Travel (pp. 3-22),Bristol : Channel View Publications.

Sharpley, R.\& Stone, P.R.( Eds.) (2009). The Darker Side of Travel,Bristol : Channel View Publications.

Sharpley, R., \& Stone, P.R., (2009). (Re)presenting the macabre : interpretation, kitschification and authenticity. In Sharpley, R. \& Stone, P.R. (Eds.).The Darker Side of Travel (pp. 109-127). Bristol: Channel View Publications.

Stone, P. (2006). A dark tourism spectrum: Towards a typology of death and macabre related tourist sites, attractions and exhibitions. Tourism, 54(2)145-160.

Stone, P.R. (2012). Dark tourism (also Thanatourism). In Robinson, M.(ed.) Tourism the Key Concepts (pp.46-49), London: Routledge.

Stone, P. R., Hartmann, R., Seaton, T., Sharpley, R., \& White, L. (Eds.) (2018).The Palgrave Handbook of Dark Tourism Studies, Palgrave Macmillan , U.K.

Tang, Y. (2014). Dark touristic perception: Motivation, experience and benefits interpreted from the visit to seismic memorial sites in Sichuan province. Journal of Mountain Science, 11(5), 1326-1341.

Tang, Y. (2018). Contested narratives at the Hanwang earthquake memorial park : Where ghost industrial town and seismic memorial. GeoHeritage, Author's personal copy.

Tarlow, P.E. (2005). Dark tourism: The appealing 'dark' side of tourism and more. In Noveli, M.(Ed.). Niche Tourism: Contemporary Issues, Trends and Cases, London, Routledge.

Tita, N. (2010). Bachelor's Thesis in Nature and Soft Adventure, Submitted to the Lahti University of Applied Sciences.

Walter, T. (2009). Dark tourism: Mediating between the dead and the living. In Sharpley, R.\& Stone, P.R.( Eds.) (2009). The Darker Side of Travel (pp.39-55), Bristol: Channel View Publications.

Wang, N. (1999). Rethinking authenticity in tourism experience.Annals of Tourism Research,26(2), 349-370.

White,L.\& Frew, E.(Eds.) (2013).Dark Tourism and Place Identity: Managing and Interpreting Dark Places, London: Routledge.

Williams, P. (2010). Educational tourism: understanding the concept, recognising the value. https://www.cabdirect.org/cabdirect/abstract/20103311195

Yan, B.-J., Zhang, J., Zhang, H.-L., Lu, S.-J., \& Guo, Y. R. (2016). Investigating the motivation-experience relationship in a dark tourism space: A case study of the Beichuan earthquake relics, China. Tourism Management, 53, 108-121.

Yousaf, A., Amin, J., \& Santos, J. A. (2018). Tourists' motivation to travel: a theoretical perspective on the existing literature. Tourism and Hospitality Management 24 (1), 192-211.

Yull, S.M. (2003).Dark tourism: understanding visitor motivation at sites of death and disaster, An Unpublished Master's Thesis Submitted to the Office of Graduate Studies of Texas A\&M University. 